\title{
Lexis
}

Journal in English Lexicology

$8 \mid 2014$

Metaphor Studies in the English Language

\section{When history becomes a metaphor for the present and the future: recent far-right discourse about immigration in the UK}

Anne Friederike Delouis

\section{(2) OpenEdition \\ Journals}

Electronic version

URL: http://journals.openedition.org/lexis/219

DOI: $10.4000 /$ lexis. 219

ISSN: 1951-6215

\section{Publisher}

Université Jean Moulin - Lyon 3

\section{Electronic reference}

Anne Friederike Delouis, « When history becomes a metaphor for the present and the future: recent far-right discourse about immigration in the UK », Lexis [Online], 8 | 2014, Online since 09 January 2014, connection on 19 April 2019. URL : http://journals.openedition.org/lexis/219; DOI : 10.4000/ lexis. 219

This text was automatically generated on 19 April 2019.

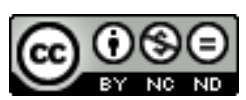

Lexis is licensed under a Creative Commons Attribution-NonCommercial-NoDerivatives 4.0 International License. 


\title{
When history becomes a metaphor for the present and the future: recent far-right discourse about immigration in the UK
}

\author{
Anne Friederike Delouis
}

\section{Introduction}

[...] put in simple terms which are undeniable and obvious in so many news stories and incidents that listing them would require an entire library, it is the ethnic groups who invade the UK that have the protection and backing of thoroughly biased British 'law', whereas the indigenous English [...] do not have any rights to protect themselves as a recognized racial and tribal group from the effects and cultural ravages of this foreign mass colonization [...]

[Waerloga, "The Indigenous British - A Denial of Rights Conspiracy", www.bnp.org.uk, 22 August 2012]

1 Far-right discourse is peppered with multiple metaphors such as in the example above. Perhaps even more so than their left-wing counterparts, nationalist and xenophobic politicians need to resort to tropes in order to illustrate their worldview which they construe as a radically different counter-model to mainstream understandings.

Immigration looms large in far-right texts. It is considered to be the virtually unique cause for all ills that befall contemporary society. ${ }^{1}$ Metaphor scholars have taken interest in the far-right discourse on immigration in various countries and identified the most common metaphors used to refer to the arrival of new populations: water, war [Hart 2010: 144], animals [Santa Ana 1999], and disease [Musolff 2011: 6]. John Charteris-Black analysed immigration metaphors in the context of the 2005 general elections in Britain. He singled out two metaphors in particular which both pertain to the general source domain of liquids. An overflow of liquids in nature can cause a natural disaster such as 
flooding; excessive liquid in a container leads to overspill or bursting. Both concepts applied to the immigration situation in Charteris-Black's right-wing corpus [CharterisBlack 2006: 570]. The author called for comparative studies, both with a synchronic approach, i.e. comparing the metaphors used by politicians or commentators of different political persuasions, and in a diachronic perspective, so as to trace any changes in the most frequent metaphors [Charteris-Black 2006: 580].

One aim of this article is to provide a basis for such comparisons. Arguably, "war" and "conflict" metaphors have become a more prevalent interpretative frame than "liquid" and "container" tropes in recent years. Martial metaphors such as "conquest" or "invasion" enables a semantic slide which transforms foreigners into "enemies" and seemingly justifies radical "emergency" measures against immigration. What other truth claims do recent immigration metaphors entail? To what affects or emotions do they appeal? What notions of time and visions of the future do these implicit references to historical events convey?

3 The corpus under consideration includes election manifestoes as well as information material released on the internet pages of the British National Party. ${ }^{2}$ It consists of official leaflets to be distributed by militants, but also, and mostly, of articles ranging from reports on local incidents to sweeping reflections on the course of world history. This "BNP corpus" comprises 56 texts published between July 2011 and February 2013. They amount to a total of 61,105 words, with text length varying from 120 to 4700 words. Written by party leaders and members, ${ }^{3}$ these texts often resemble oral discourse in their tone, drawing on a wealth of metaphors to convince and perhaps even convert readers to a right-wing worldview.

\section{Immigration as a topic in the 2005 and 2010 elections}

4 To put far-right figurative discourse on immigration into perspective, a brief analysis of the manifestoes released by the most important parties ${ }^{4}$ prior to the 2005 and 2010 general elections should prove useful.

In what ways was the topic of immigration dealt with by different parties, and what changes can be observed?

5 Migration or immigration features in every manifesto, indicating that parties identified the issue as a topic that concerned voters in both elections. In sheer quantitative terms, engagement with the topic varies from a couple of sentences (Green Party and Liberal Democrats in 2005: 6 occurrences of "(im)migration" and "migrants" respectively) to a clearly dominant theme: 58 occurrences of "(im)migration" and "immigrants" in the 2005 BNP manifesto, for instance.

6 The immigration issue tends to be included either in sections on the economy or in chapters on home affairs. This thematic framing indicates the general assessment of the topic: viewed from an economic angle, immigration bestowed a "positive [...] benefit" on Britain, making it "one of the richest countries in the world", as far as the Liberal Democrats were concerned prior to the 2005 elections, for example [Liberal Democrats 2005: 11]. 
7 Yet in 2005, most political parties discussed immigration in the context of home affairs, showing that they believed migrants had to be controlled and policed. The 2005 Labour manifesto includes immigration in a chapter on "Crime and security". The first occurrence of the term is in a list of important issues to be tackled, followed by "international terrorism". Labour's 2005 message on immigration was twofold: migrants contribute to economic growth and bring benefits for Britain, a country that prides itself on its hospitality; but there has to be a "crackdown on abuse", the borders must be "strong and secure", the immigration system "robust and fair" [The Labour Party 2005: 51-53].

8 The Conservative Party displayed a similar Janus-faced approach to immigration in its 2005 manifesto, while pandering more to emotional aspects than the Labour Party did. In the foreword, the topic was lumped together with a hotchpotch of other issues including dirty hospitals, infection, criminals and the fear they inspire in responsible citizens. This association is far from coincidental as the Conservative Party backed compulsory health checks for newly arrived immigrants (a proposition dropped in 2010) and listed controlled immigration as a means of reducing terrorist threats. The immigration and asylum systems are portrayed as being out of control, badly managed, "in chaos". There was however an introductory sentence which nodded to the benefits of immigration, "the economic vibrancy and cultural richness that immigration brings" [The Conservative Party 2005: 19]. The two main political parties generally try to cater to a broad spectrum of voter sensibilities, while smaller parties take less ambiguous stands. The UKIP manifestoes demand limits on the number of immigrants allowed to enter the country as well as tougher deportation measures. Immigration is highly salient in the BNP manifestoes to the point of being cast as a matter of life or death for the British nation.

9 On the opposite side of the political spectrum, the Green Party discusses immigration neither in terms of law and order, nor does it apply a cost-benefit analysis to the matter. This party deals with "migration", a term seemingly preferred to "immigration", in the context of international policy, which leads to a global and ethical perspective. As a consequence, the party advocates more rights for asylum seekers and economic migrants, including the legalisation of illegal immigrants so as to protect them from economic exploitation in the UK [The Green Party of England and Wales 2005: 28, and 2010: 45].

10 Five years later, following the London bombings two months after the 2005 election and the economic downturn, a toughening was to be expected. The 2010 Labour manifesto signalled understanding for "people's concerns" about immigration and an interest in reducing immigration figures. The Conservative Party would still stress the "enrichment" brought about by migrants while wanting to reduce their numbers. Most significantly perhaps, the Liberal Democrats moved the immigration issue from an economic context to a chapter on crime. A part of the vocabulary was borrowed from the 2005 Conservative manifesto (a "system in chaos") or coincided with words used in the 2010 Labour manifesto ("firm and fair" processing of claimants), thus illustrating the party's centrist stance. The UKIP gave more weight to the alleged link between crime and illegal immigrants than in 2005, while the words chosen by the BNP ("impending extinction", "threat to survival" of the British) had an even more dramatic ring to them in 2010.

11 A comparison of the 2005 and 2010 election manifestos goes to show that parties trying to appeal to a significant part of the electorate toughened their stance on immigration, either by demanding quantitative limits or by hinting more explicitly at a supposed link between immigration and crime. Immigration became a seemingly more urgent topic 
which no party could afford to ignore. In this context, it was to be expected that statements on immigration policy would intensify in tone.

Official and semi-official BNP publications display particularly colourful language when dealing with immigration, the single most appealing topic to this political party. They provide promising material for the study of metaphor.

Typical immigration metaphors such as IMMIGRATION IS A DISEASE ${ }^{5}$ and IMMIGRATION IS A FLOW or a FLOOD can still be found in the latest BNP statements. However, complex metaphors with historical resonance have become more salient in recent years. A close reading permits to identify a number of such metaphors, three of which have been singled out for analysis on account of their frequency and productivity.

The metaphors of "conquest", "colonisation", and "ethnic cleansing" are spun out in detail and across a number of texts. Arguably, these tropes could be restated to make apparent an underlying conceptual metaphor: IMMIGRATION IS WAR. However, this article sets out to prove that it is worthwhile to pitch one's analysis at the more complex level of the tropes that are actually brought into play. What interpretations of contemporary immigration to the UK do these three metaphors convey, in what ways do they refer to history, and what reactions are they hoped to elicit?

\section{Conquest}

The conquest metaphor figures in this BNP article title (8 January 2013) for example:

"Is the Islamic Conquest of Oswestry Being Orchestrated from Birmingham?"

"Conquest" refers here to the transformation of a former church into a mosque. Oswestry is a small town in Shropshire, at $100 \mathrm{~km}$ distance from Birmingham, where the Oswestry Muslim Society is apparently registered. This sets off a range of conspiracy theories.

War metaphors imply the opposition of two forces pitched against each other, often one being cast as the aggressor and the other as a victim [Lakoff \& Johnson 1980: 4-5; Steuter \& Wills 2008: 10]. While sustaining such a dichotomous view of society (autochthonous non-Muslim British vs. Muslim immigrants), the conquest metaphor is more specific in that it suggests the occupation of British soil by an invading enemy. Wars can be waged for many reasons and with different objectives; conquest aims at the annexation of foreign territory and regime change.

The British Isles were conquered twice in a thousand-year interval, which might provide the source domain for the IMMIGRATION IS CONQUEST metaphor. The collocations "Roman" and "Norman" count among the three adjectives that are most frequently associated with "conquest" in the British National Corpus (the other one being "Spanish"). ${ }^{6}$

However, the Norman conquest has come to be seen as constitutive of a nation-building process rather than an alien yoke that had to be shaken off. An anonymous BNP author is at pains to explain the difference between $11^{\text {th }}$ century and contemporary Britain:

The Viking founder of Normandy was a Norwegian named Rolf, later called Rollo, and some Normans still had Scandinavian names at the time of the Conquest. The peoples of Saxon England were not so very different from one another and, above all, they were wonderfully pliant and malleable in their admixture with those they settled among.

All belonged to the same broad culture as southern Scandinavia, Germany and northern France. By the time of William's son Henry I there was no difference even 
between Norman and Saxon. [...]

The Norman aristocracy simply became the ruling class of a country whose army they had destroyed.

The period of history between the coming of Hengist and Horsa and the Norman Conquest was fundamentally different to what is happening now.

[The Coming of the English, by Man of Kent, www.bnp.org.uk, 12 February 2013]

If it proves necessary to give explanations and to point out the differences from the most obvious source domain, should one conclude that the "conquest" metaphor is a rather less felicitous choice from the users' point of view? Not entirely, for from what can be gleaned in BNP-endorsed publications, the preferred source domain is located outside Britain and in another historical era, as the title about the Oswestry mosque indicates: the "Islamic conquest", i.e. the expansion of Muslim rule in the $7^{\text {th }}$ and $8^{\text {th }}$ centuries.

For those less knowledgeable in the history of Islam, a range of far-right literature explaining the political and religious principle of "conquest" is available. For instance, a certain Edward Hellaby proposes an extensive compilation of re-ordered Qur'an verses taken to illustrate a "strategy for conquest":

All is not as it seems. To understand what's really exciting so many Muslim 'radicals', you need to understand how Muhammad conquered Medina and that the instructions he gave before, during and after this conquest are recorded in the Qur'an as the 'everlasting word of God'. [Edward Hellaby, 'Islam and the Qur'an: A strategy for conquest", www. bnp.org.uk, 15 February 2013]

Deceiving non-Muslims is believed to be an integral part of this strategy. This is why any peaceful Qur'an passages are disqualified from the outset. They are thought to set up a façade designed to hide the true objectives of Islam, then and now: "Islam is not a democratic organisation, believing in World domination, therefore can it [be] trusted? Islam is at the very core anti-democratic because it is a religion of conquest, by sword or by the book." [Northernscot, "Will lessons of the past ever be learnt?", www.bnp.org.uk, 20 June 2012].

3 In this process of apparently deliberate metaphor creation, past military conquests (of Mecca in 629 , or Spain and India in later centuries) are construed as a blueprint for present-day "conquest" of Britain.

24 Mohammed and his followers serve as a metonymy for today's Muslim believers. ${ }^{8}$ The overall aim of achieving domination over the West is supposed to remain the same, while the "weapons" have changed: "birth and migration" [Hellaby, op. cit.], "immigration and differential birthrates" [Nick Griffin, "Islamic Europe? No, because Europe is ours!", www.bnp.org.uk, 19 April 2012].

Islamic conquest as a metaphor results in a telescopic view that equates present-day Muslims living in Britain with seventh- and eighth-century Arab conquerors. Eventually, the associated metaphorical mappings give credence to claims that Islamic practices, and by extension, the behaviour of certain Muslims, is less "civilised". ${ }^{9}$

Contemporary Islamic "conquest" is described as a slow and stealthy process. It easily escapes the attention of less vigilant citizens. A disquieting dystopia set in 2066 Britain spells out the potential extent of such a "Muslim conquest": A Muslim Prime Minister receives "top Muslim theocrats" in Downing Street, the police force is peopled by Muslims, non-Muslims are in social and physical decline. "William the Conquered", the senile king, is unable to cope with the situation. A Muslim delegation asks him to marry his granddaughter to a Pakistani groom: "They hope this will strengthen the legitimacy of 
what is in effect a conquest." [Man of Kent, "William the Conquered", www.bnp.org.uk, 22 February 2012].

The choice of the year 2066 is not fortuitous: 1000 years after the Norman Conquest, Britain is conquered again, in a different way and by a different enemy. 66 may also allude to the "number of the beast" as Britain under Muslim rule resembles an apocalyptic scenario, as far as far-right militants are concerned.

Every little "progress" in the "Muslim conquest" of Britain has to be seen as a "warning sign", which justifies far-right mobilisation against local projects such as the setting up of an Islamic centre. "Conquest" remains associated with the annexation of foreign territory. This is why incidents highlighting the purchase or lease of land and real estate figure prominently in "conquest" narratives. Deceit is described as an integral part of the "strategy", which disqualifies representatives of Muslim communities as honest partners in political dialogue.

The "conquest" metaphor differs from "war" for the reason that it concerns every single citizen as the sheer existence of the polity is seen to be at stake. As a result, it is meant to conjure up "anger" and "rage". ${ }^{10}$ This metaphor alludes to former Islamic conquests and is more specific than IMMIGRATION IS WAR in that it makes reference to immigration from Islamic countries and the visible presence of Muslim practice on British soil, which are particular preoccupations of the far right. If it catches on with a broader public, beyond BNP members, IMMIGRATION IS CONQUEST might prove a singularly effective metaphor for the extreme right.

\section{Colonisation}

"Colonisation" metaphors are sometimes applied to the very same situations, as for example the mosque building project at Oswestry:

Shropshire Patriot believes that the colonisation of Britain by Islam is a highly co-ordinated affair, and we think that claims by Muslim community leaders that the opening of new mosques are merely 'local initiatives' is an exercise in propaganda aimed at keeping our people in the dark until the force of Islam is powerful enough to take over our society. ["Is the Islamic Conquest of Oswestry Being Orchestrated from Birmingham?", www.bnp.org.uk, 8 January 2013]

31 Conspiracy theories and the accusation of stealthy progress and deceit are thus also associated with "colonisation", as can be seen in the following quotation of a "local organizer", concerned by the future mosque:

I believe this application has been carefully timed to catch local people unawares as they prepare for the festive period. Furthermore, the word 'Mosque' has been deliberately omitted in this 'softly-softly' approach towards the gradual colonisation of Oswestry. ["Oswestry Muslim Society Submits Plans for Prayer Centre", www.bnp.org.uk, 5 December 2012]

Apart from religious centres, the opening of foreign-looking shops and restaurants are perceived as further instances of "colonisation", especially when they are grouped together in a single street or area:

This is a typical case of stealth migration, five years ago there was hardly a Muslim to be seen in Winton, over the five years following the arrival of a mosque and its recent expansion they have trickled in, property is bought up, the shops are changing very slowly, 99p shops, Muslim barbers opening, it all looks harmless but that is the point, it creeps in. Islam is not a religion of peace, it rejects integration, 
indoctrinates its children to reject Christianity until there are enough to take over and carry out the colonisation of areas. [A Dorset Activist, "A 2 part report into the stealth islamification of Dorset", www.bnp.org.uk, 21 January 2012]

In this description of recent changes in the urban landscape of Bournemouth, two conceptual metaphors convey the supposed characteristics of immigration: its slow but steady progress (trickling in) and stealthy advance (creeping in). Metaphors of liquidity and animality are complementary to the more complex colonisation metaphor, and perhaps necessarily so. One contributor to the BNP website notes that British citizens have not had any direct experience of colonisation, unlike Indians for example. As the memory of colonial times is still fresh in their minds, the latter supposedly react immediately to developments that are perceived as metaphorical colonisation, such as the expansion of multinational supermarket chains [Sheila Spink, "Globalisation is the new colonisation", www.bnp.org.uk, 21 September 2009].

The "colonisation" metaphor reaches further than the "conquest" trope in that it is not necessarily connected to the acquisition of property, the transformation of buildings and takeover of political power. Other supposed instances of the "colonisation" of Britain are birth rates and population statistics, eagerly discussed in far-right circles, particularly in the wake of the recent census (2011), as well as the "grooming" of young girls in cases where the perpetrators are of foreign descent:

It is this cold blooded and totally alien concept of using another country's children that is mind boggling and it has to be stopped. It is the lowest way of colonisation and should be seen as such. [Lynne Mozar, "ProFam - Protecting the Family", www.bnp.org.uk, 1 October 2010]

"Grooming", the sexual exploitation of girls, is an interesting target of the "colonisation" metaphor as it actually involves abusive and predatory behaviour of the kind one generally associates with colonialism. However, with so little tangible evidence to support an alleged "colonisation" of Britain by immigrants, would one not be tempted to conclude once more that the far right has chosen a rather skewed and improbable metaphor, unlikely to catch on with a larger public?

However, a closer analysis of the mapping processes implied proves the pertinence of this metaphor: if immigrants are the new colonisers, the British are an "indigenous people" deserving "protection" under international law. The obvious absence of any "protective" measures permits to indict the government of the country. Allegedly duplicitous political leaders apply double standards and betray the people in their charge - a favourite accusation with far-right militants. "Indigenous Britons" is an oft-used expression to designate the majority population which is supposed to have more rights than foreignborn British citizens. A BNP website contributor spells out his dismay at length:

[...] the indigenous English people now actually have fewer rights than the indigenous Aboriginal peoples of Australia.

The United Nations Development Group Guidelines on Indigenous People's Issues [... ] even provides a list of what it calls "Guiding Principles" in which the rights of indigenous people are detailed.

These are, in fact, the "rights" which the indigenous English race in England do not have in British law, simply because our government refuses to recognize the existence of the English as an indigenous people in England. [...] There are many more recommendations in this UN document, but the few examples given here amply serve to demonstrate why the British government refuses to recognize the native English race as indigenous to England.

If they did so, their cherished scheme for producing enforced multiculturalism and 
eliminating the English race from interfering with future history would be shot full of holes and sunk.

The last thing the government wants is to allow the rightful indigenous English race to have any recognized indigenous rights as detailed in UN Convention 169. [Waerloga, op.cit.]

Intended or not, the reiteration of almost identical phrases makes a forceful case for the existence of an "indigenous English people" which is ignored by the government. In the minds of some militants, the alleged treason orchestrated by the political class goes as far as to wage a "war" against its own people:

My mother first saw a knife fight aged 10 on the streets of Smethwick near her home. It was a fight between rival Asian gangs. That was 50 years ago, and the colonisation of Britain has been taking place ever since, via immigration and high birth rates. [...] In recent years I have come to some startling yet accurate conclusions; Mainstream politicians say one thing and do the opposite. Immigrant numbers rise no matter whether we have a Labour or Conservative or Lib Dem government. The British government has no control over the laws which govern British citizens. Our towns and cities are no longer British; they are little versions of Islamabad, Somalia and Iraq. The war on terror should be fought here on the streets of Britain, not on the streets of Afghanistan. Our country's population is changing at an alarming rate. The government which is supposed to protect us has imported what amounts to a foreign army, many of whom hate the people whose country they are now living in, and at the same time our government has sent our troops as far away as is possible to go, into wars which are impossible to win. [Philip Reddall, "The British National Party - A Grassroots Perspective", www.bnp.org.uk, 17 March 2012]

In the light of these accusations, the 2005 BNP proposal of withdrawing troops from Iraq and stationing them at the Channel Tunnel seems almost logical [BNP 2005: 13]. The IMMIGRATION IS CONQUEST / COLONISATION metaphor would have become a reality then; invading "colonial troops" would be fought back by a real army.

The IMMIGRATION IS COLONISATION metaphor begs a key theoretical question: what precisely is its source domain? In accordance with conceptual metaphor theory, one would look for the most basic sense of the word. The BNC contains 257 occurrences of "colonisation", 90 of which pertain to the field of biology or ecology, such as in the colonisation of an organism by bacteria or the colonisation of an area by a plant species. However, these examples stem from scientific publications, whereas the historical-political context of colonisation seems to be more prevalent in everyday language. An almost equal number of matches (88) concern colonisation in modern times..$^{11}$ Despite the quantitative (but biased) evidence of the BNC, it seems that the apparently more concrete, but actually more learned biological dimension of "colonisation" is rather irrelevant in the far-right corpus under consideration. Even in its more elaborated forms, as in the quotations above, the metaphor never implies any link with the microbiological or ecological considerations. IMMIGRATION IS COLONISATION appears to be a truly historical metaphor.

\section{Ethnic cleansing}

"Ethnic cleansing", the third trope under consideration, involves the difficulty of imbricated metaphors: "cleansing" is a metaphorical euphemism for killing or expelling a population group, referring to the underlying conceptual metaphor THE ENEMY IS DIRT. ${ }^{12}$ Far-right militants sometimes use the metaphor in its primary sense, mostly to evoke 
situations when Muslims and/or Blacks attack or expulse Christians and/or Whites (Cyprus, Southern Africa, Nigeria, among others), which chimes with the BNP's racialist bias. By contrast, the latest example of "ethnic cleansing" that was fresh in people's mind when the BNC was compiled, i.e. Serbian militia killing Bosnians and expelling Kosovars (47 out of 49 occurrences in the BNC), is omitted or downplayed by far-right authors. Muslim victims do not fit the worldview they would like to propagate. Conversely, communist regimes are frequently accused of instigating ethnic cleansing in these texts.

41 Applied to present-day Britain, "ethnic cleansing" alludes to population statistics, such as the high number of babies born to immigrant parents. ${ }^{13}$ It also denotes the changing population makeup of some neighbourhoods, particularly in "Refugee Camp London":

For the first time as far back as records go, white British Londoners are a minority in their own capital city, having been ethnically cleansed and replaced by hordes of illegal immigrants. [...] A cursory glance at official statistics, which will have been massaged downwards in an attempt to placate the indigenous inhabitants, clearly shows the criminal Nazi-Labour style ethnic cleansing areas. Brent $55.1 \%$ born outside Britain; Camden $42.5 \%$ born outside Britain; Ealing 48.2\%; Hammersmith \& Fulham 42.8\%; Haringey 44.6\%; Harrow 44.8\%; Hounslow 43.1\%; Kensington \& Chelsea 51.6\%; Newham 53.7\%; Westminster 53.5\%. [John Ball, "Refugee Camp London”, www.bnp.org.uk , 28 December 2012]

Some of these immigrants must be quite affluent to be able to buy or rent property in upmarket neighbourhoods like Kensington \& Chelsea, yet in his effort to amplify the phenomenon, the author lumps all foreign-born residents together into the single category of "illegal immigrants". Alleging that immigrants arrive in "hordes" is designed to make them appear hardly civilized, yet organised and dangerous. Rather peaceful behaviour of moving into a new neighbourhood thus resembles an act of aggression. Even a trivial observation such as the Eastern European accent of a bank employee triggers thoughts about the "ethnic cleansing" of London neighbourhoods.

Favourite anecdotes meant to illustrate "ethnic cleansing" feature white British-born victims set under pressure to leave their homes or businesses, such as a non-Halal butcher closing his shop opposite a mosque in Lancashire ${ }^{14}$, and a "defenceless 84 -yearold pensioner [who] shares her story of harassment, intimidation and attempts of forcible displacement with BNPtv" ["Shocking: Ethnic Cleansing in Rotherham", www.bnp.org.uk, 14 January 2013]. This filmed interview conjures up memories of the elderly lady whom Enoch Powell mentioned in his infamous 1968 "Rivers of Blood" speech. Giving the impression that the very old and the very young, such as in the sordid grooming cases, are the preferred victims of immigrant bullies or criminals, is bound to trigger emotionally charged reactions and, for the very least, the desire to protect particularly vulnerable members of the community, serving as a metonym for the nation as a whole. Occurrences like these are particularly likely to enthral the public imagination when they fit a number of typical national narratives and frames at once [Lakoff 2008: 33]. In the same vein, BNP leaflets would also oppose British children and pensioners with foreigners. ${ }^{15}$

The fact that in both cases, i.e. grooming young girls and harassing elderly neighbours, the victims are women deserves some further comment in this context. Chris Waters showed how from the 1930s, the British nation was increasingly imagined in more feminine, domestic terms. Following the immigration waves of the 1950s, public anxieties concentrated on women's safety. Strangers were portrayed as primitive savages bent on sexuality and violence, not unlike stereotypes about the working class in the $19^{\text {th }}$ century 
[Waters 1997: 227]. Harm done to women is likely to take on a particular resonance in nationalist minds. Attacking aged and young women alike, Muslim men may appear to assail the past and the future of the nation.

Labelling demographic changes as "ethnic cleansing" conveys a sense of urgency: the process must be stopped or reversed before it is too late. As a source domain, "ethnic cleansing" involves killing and other forms of violence, an association that is reinforced by the related metaphors of "genocide" and "national suicide", equally used by far-right spokespeople. To spin the metaphorical implications further: if there is "murder", someone needs to be held to account for this "crime". A "hostile Muslim community" may be blamed in some cases, but the "ethnic cleansing" metaphor mostly targets the government. Why should the political leadership of Britain be intent on "replacing" the population? If pressed to supply an answer, far-right thinkers would contend that the political leadership is deluded by certain ideologies, such as liberalism:

Liberals champion multiculturalism, they formulate and enact diversity requirements and push through immigration into working class areas, thus ethnically cleansing these localities [Imnokuffar, "What is a Liberal/Communist or Socialist?", www.bnp.org.uk, 3 February 2013].

The "delusion" might as well stem from "Marxism, or Cultural Marxism" and thus the denial to recognize that races exist, according to another posting [John Salvage, "Race, Nation, And the Perpetual Lie", www.bnp.org.uk, 9 January 2013]. Others allege that the entire leadership is "Communist", not only "New Labour's son of an illegal red immigrant Miliband" [John Salvage, "Liberals versus Marxists... The Ultimate Battle", www.bnp.org.uk, 21 December 2012], but also "Tony Blair, Gordon Brown, David Cameron, Michael Gove, Kenneth Clarke, Nick Clegg,[...] Jack Straw(vinski), Peter Mandelson, Harriett Harman, Merkel, Barrosso [sic], Rompuy, etc etc etc." [Jack Whitby, "The Labour Party Conference in Manchester and Communism", www.bnp.org.uk, 4 October 2012].

47 A disloyal and deluded government "condones ethnic cleansing" by tolerating immigration, as the BNP sees it. Incidentally, the "Westminster establishment" is also supposed to be complicit in the "long war of cultural genocide and ethnic cleansing against the loyalist community" in Northern Ireland. ${ }^{16}$

While the motive remains somewhat unclear, the perpetrators are thus clearly identified: accusations of "ethnic cleansing" are levelled against the BNP's political opponents. They even permit party leaders to indulge in fantasies of "nationalist" takeover and subsequent criminal trials. The account of "criminal Nazi-Labour style ethnic cleansing" in London quoted above concludes:

These examples of ethnic cleansing are worse than anything that happened in the Balkans, whose politicians and generals were branded war criminals. Our leaders, who committed this crime on us, should be in prison.

They walk free today, but one day a Nationalist government will bring these traitors in front of a criminal court.

We will try them for crimes of genocide and ethnic cleansing of the citizens of London and justice will be done. [John Ball, op.cit.].

Elsewhere, an anonymous author writes: "Nuremberg rules will apply." ["Emma West More bullying from the Tory state", www.bnp.org.uk, 3 January 2012]. between a blameworthy intellectual and political elite that "colludes" with immigrants 
and possibly the EU on the one hand, and the majority population on the other. As a result, the far right can present itself as the only political force that criticizes the former while championing the latter, i.e. its desired electorate.

\section{Discussion}

51 All the metaphors under discussion - conquest, colonisation, ethnic cleansing - are obvious hyperboles. They aggrandise isolated incidents out of proportion, making them appear to be stepping stones towards the disappearance of the country as people knew it. Taken from the terminology of historiography, they place the interpretation of current affairs in the context of world history. Trivial matters - a new shop, a new neighbour, the accent of an employee - are given an added importance in this light.

On ethical grounds, one may want to condemn the use of these metaphors because they minimise the plight of the victims of real colonisation and ethnic cleansing. On the level of textual or rather intertextual analysis, one might understand these tropes as a kind of post-modern pastiche, with far-right militants helping themselves to the toolkit of liberal political thought. However, a thorough examination of far-right accusations against their political or intellectual opponents reveals that the procedure of turning criticism around is rather systematic. Political leaders and the media are supposedly "supremacists" and "Fascists", "intent on destroying our society, freedoms and imposing a totalitarian regime on all of us" [Imnokuffar, "Liberal/Marxist Fascism and Totalitarianism - an Explanation", 22 November 2012]. All these labels (fascist, supremacist, totalitarian) are designed to drive home the point that the real "Fascists" are to be found on the other side. Just as the far right is marginalised in the public sphere, the British and their traditional way of life are supposedly targeted by Labour's and the coalition's immigration policies. The arguments and metaphors used by the BNP create a community of victims. The successive governments appear all the more "hypocritical" as they may well defend indigenous rights and condemn ethnic cleansing outside Britain, but orchestrate a "cultural genocide" or "national suicide" in their own country. In relying on precisely those metaphors, i.e. "conquest", "colonisation", and "ethnic cleansing", farright militants make a subversive use of mainstream thought. Few people would want to defend any of these violent actions in the beginning $21^{\text {st }}$ century, ${ }^{17}$ so readers or listeners should automatically enlist with those criticising these ills, i.e. in this case the far right, and defend the victims, i.e. white and/or non-Muslim British citizens. Those who refuse to accept this argument are labelled "bigots". In the end, the chain of argumentation triggered by the metaphors discussed results in the conviction that one cannot debate with mainstream politicians and media at all. Likewise, Islamic "conquest" is supposed to include deceit, which implies that Muslims cannot be believed when they talk of peace. This is where the figurative discourse used by the far right becomes inherently antidemocratic. Eventually, operating with terms such as "conquest", "colonisation" and "ethnic cleansing" precludes any debate with either political opponents or the Muslim community of Britain.

War metaphors often mute any internal discussion [Steuter \& Wills 2008: 11]. One BNP authors spells out this dichotomy in no uncertain terms:

The British National Party is the only party committed to stopping the hastening destruction of our race and our country, and preventing the erasure of thousands of years of our history and our culture. 
You're either in favour of the genocide of the British people, or you're in the British National Party. There is no middle ground. There is no other option. ["One-third of births in Britain are to foreign parents", www.bnp.org.uk, 30 August 2011].

54 This extreme example shows where the association of immigration with crime ultimately leads: wholesale condemnation, virtual closure of the borders and perhaps even expulsion of immigrants in the last instance as there is no argumentative space for defending a crime, especially such a particularly horrid one as genocide.

In his analysis of discourse on immigration in the 2005 election campaigns, Jonathan Charteris-Black had focused on "liquid" metaphors. The presumed danger of immigration was signified by the increase of liquids: a trickle becoming a flow, a rising tide, a flood, a bursting container. The prevalent metaphors have changed, but their processual connotation has remained the same. Historical metaphors also indicate an evolution. Conquest, colonisation, and ethnic cleansing are processes which may be more or less advanced. This is why single incidents can be interpreted as "warning signs", bound to occur again and again. A local phenomenon is thus aggrandized by assuming that is part of a larger process.

The 2005 metaphors such as "flood" and "bursting" are "disasters", as Charteris-Black analysed; metaphorically, they damage or destroy the country. Present-day metaphors suggest the future disappearance of the UK in an even more explicit manner. The extreme metaphors of "national suicide" and "genocide" leave no doubt as to the imagined outcome of immigration. ${ }^{18}$

Should one conclude that eight years ago, immigration metaphors were used in a more implicit, perhaps even subconscious way, with images of water appealing to primal fears of drowning, while today's right-wing discourse on immigration might have become more self-conscious and deliberately constructed?

Traditionally, historical analogies are often used to explain the meaning of events, to determine the lessons that are to be drawn from the past, anticipate problems and identify warning signs [Houchin Winfield, Friedman, Trisnadi 2002]. As such, they appear to belong to the domain of scholarly discourse. In the far-right texts under discussion, historical metaphors are certainly hoped to give a rational, perhaps even academic appearance to a number of political arguments. However, contrary to truly heuristic historical analogies, the "conquest", "colonisation", and "ethnic cleansing" metaphors distort reality beyond recognition. The most extreme example is surely the highly paradoxical metaphor of GIVING BIRTH IS KILLING, when births to foreign mothers are likened to genocide of the white British population.

59 Paul Chilton discusses historical analogies separately from metaphors on account of the formal reason that their source domains are fixed in space and time, while admitting that the inferential processes associated with metaphor and historical analogy are similar [Chilton 2004: 149]. The examples discussed in this article clearly show (1) that historical metaphors are by no means limited to scholarly or high-end journalistic publications, and (2) that they are designed to trigger strong emotions, enlist and rouse supporters just like any other conceptual political metaphor. Arguably, the role played by memory in the activation of historical metaphors might single them out as a particular subgroup, especially when people personally remember the historical facts in question [Crawford 2000: 145]. In other cases, the source domains may appear more remote, only accessible 
through mediation of news reports, history lessons or historical readings. Does this imply that they lack the supposed embodied immediacy of typical conceptual metaphors?

Few people have first-hand experience of flooding and yet it is widely accepted that this metaphor provokes emotions similar to a fear of drowning. However, just as they may imagine an inundation, people can conjure up images of genocide or ethnic cleansing and experience fear of being killed. While the emotional impact of historical metaphors is not necessarily less significant, these tropes tend to be more precise, or less universal, than typical Lakovian metaphors. "Conquest" and "colonisation" convey additional messages targeting particular characteristics of the "enemy" (Muslims always have been and always will be intent on conquering non-believers' territories; Muslims are not to be trusted; Communists have a propensity to internationalism and will betray their own people, and so on). In that, these tropes are certainly of a more "deliberate" nature than the liquid and container metaphors examined by Charteris-Black in 2006.

Historical metaphors look to the past, for instance to the era of Islamic conquests in the early Middle Ages, the heyday of British colonialism, and ethnic cleansing in former Yugoslavia. They transfer the distinctive features of these periods to present-day Britain. At the same time, these metaphors contain predictions of the future, announcing the disasters that supposedly are to weigh down the country. Most importantly of all, these kinds of historical metaphors carry moral judgements. Colonialism and genocide are universally condemned. Encountering these concepts in the context of immigration creates significant semantic tension for left-wing and centrist readers, while far-right readers are certainly more likely to think that they are a good match for reality. Their slightly more deliberate nature and the specificity of history as a source domain make these metaphors neither less persuasive nor less dangerous, but might eventually facilitate a critical assessment of their suitability.

\section{BIBLIOGRAPHY}

BRITISH NATIONAL PARTY, Rebuilding British Democracy: British National Party General Election 2005 Manifesto, Welshpool, 2005.

BRITISH NATIONAL PARTY, Freedom, Culture and Identity: British National Party General Elections Manifesto 2010, Welshpool, 2010.

BRITISH NATIONAL PARTY, Our children are not halal meat, Carlisle, 2011.

BRITISH NATIONAL PARTY, Halal Meat: Shame on Britain, Wigton, 2011.

BRITISH NATIONAL PARTY, Broken Britain, Wigton, 2012.

CHARTERIS-BLACK Jonathan, "Britain as a container: immigration metaphors in the 2005 election campaign", Discourse \& Society 17: 5, 2006: 563-581.

CHARTERIS-BLACK Jonathan, “Metaphors as Models of Political Leadership”, Durham University, May 2008 
http://www.dur.ac.uk/resources/mlac/research/metaphors_as_models/Charteris2.pdf accessed on 15 February 2013).

CHILTon Paul, Analysing Political Discourse, London: Routledge, 2004.

THE CONSERVATIVE PARTY, Are you thinking what we are thinking? It's time for action. Conservative Election Manifesto 2005, London, 2005.

THE CONSERVATIVE PARTY, Invitation to join the government of Britain: The Conservative Manifesto 2010, London, 2010.

CRAWFORD Neta C., "The Passion of World Politics: Propositions on Emotions and Emotional Relationships", International Security 24: 2, 2000: 116-156.

THE GREEN PARTY OF ENGLAND AND WALES, The Real Choice for Real Change: Green Party Manifesto for 2005, London, 2005.

THE GREEN PARTY OF ENGLAND AND WALES, Green Party General Election Manifesto 2010: fair is worth fighting for, London, 2010.

HOUCHIN WINFIELD Betty, FRIEDMAN Barbara \& TRISNADI Vivara, "History as the Metaphor through Which the Current World is Viewed: British and American newspapers' uses of history following the 11 September 2001 terrorist attacks", Journalism Studies, 3:2, 2002: 289-300.

THE LABOUR PARTY, The Labour Party manifesto 2005: Britain forward not back, London, 2005.

THE LABOUR PARTY, The Labour Party manifesto 2010: A future fair for all, London, 2010.

LAKOFF George \& JOHnSON Mark, Metaphors We Live By, Chicago: Chicago University Press, 1980.

LAKOFF George, The Political Mind: A Cognitive Scientist's Guide to Your Brain and Its Politics, New York: Penguin Books, 2008.

LIBERAL DEMOCRATS, The REAL alternative [manifesto], London, 2005.

LIBERAL DEMOCRATS, Liberal Democrat Manifesto 2010: change that works for you: building a fairer Britain, London, 2010.

MUSOLFF Andreas, “Migration, media and 'deliberate' metaphors”, metaphorik.de 21/2011 ( http://www.metaphorik.de/21/musolff.pdf).

SANTA ANA Otto, “'Like an animal I was treated': anti-immigrant metaphor in US public discourse”, Discourse \& Society, 10: 2, 1999: 191-224.

STEUTER Erin \& WILls Deborah, At War with Metaphor: Media, Propaganda, and Racism in the War on Terror, Lanham: Lexington Books, 2008.

UK INDEPENDENCE PARTY, UK Independence Party Manifesto 2005: We Want Our Country Back, Birmingham, 2005.

UK INDEPENDENCE PARTY, UKIP Manifesto April 2010: Empowering the people, Newton Abbot, 2010.

WATERS Chris, “'Dark Strangers' in Our Midst: Discourses of Race and Nation in Britain, 1947-1963", Journal of British Studies, 36:2, 1997: 207-238.

\section{NOTES}

1. Including the financial crisis: "banks were forced to give housing loans to ethnic minorities to avoid being accused of racism. That whole debacle sent us into the recession that we are in now" 
[Chris Barnett, "Simon Hughes, Dept Lib Dem Leader in 'racist banks' deceit”, www.bnp.org.uk, 26 September 2012]. No explanation can be too far-fetched as long as it permits blaming immigrants.

2. The British far right is split into two political organisations, the BNP and UKIP, which has been more successful in recent by-elections. This article focuses on BNP material because this party is singularly concerned with immigration, while UKIP devotes more discursive energy to combating the EU.

3. Not all of them can be identified: Some hide behind obvious pseudonyms, others might use false names.

4. Defined as those who scored $1 \%$ or more in at least one of the two recent elections (2005 and 2010), but excluding regional parties such as the SNP and the DUP.

5. Arguably a variation of IMMIGRANTS ARE ANIMALS (= agents of disease, such as rats or microbes). Portraying a societal problem as a disease permits leaders to pose as doctors who will cure the ills [Charteris-Black 2008: 12].

6. "Norman": 58 collocates, "Spanish": 20 , "Roman": 18, according to the BNC provided by Brigham Young University (http://corpus.byu.edu/bnc/).

7. A dissenting voice reinterprets the Roman and Norman conquests as inaugurating a centurieslong opposition between the elite and the people, a common theme of the far-right which likes to promote itself as the voice of ordinary people vs. the establishment. As in other interpretations of past conquests, history is purely used to reinforce present-day ideas [John Ball, "The Rental Society part III", www.bnp.or.uk, 9 January 2013].

8. Jonathan Charteris-Black singled out a similar process in the double metonymy leading from terrorists to illegal immigrants to the entire immigrant community [Charteris-Black 2006: 574]

9. Such as in BNP leaflets dealing with halal slaughtering, often associated with abusive treatment of women ("Our children are not halal meat" [2011] and "Halal Meat: Shame on Britain" [2011]: "Animals deserve better. As a civilised people it is our responsibility to treat animals with decency"). Both - objectively unrelated - "practices" are branded "barbaric" in BNP discourse.

10. As in "The Coming of the English": "They [immigrants and political leaders] do not accept that a race that has lived in a land for 1,500 years, with that land being named after them, has the right to be called indigenous.

In this dire situation, our only salvation is our anger.

We need an anger that is cold, lucid, rational, a fury that eliminates any detachment, any indulgence.

We need rage - armed with a knowledge of our history that is ignored or denied by the newcomers and our traitors."

Knowledge of history is seen as a "weapon" in the "war" against foreign "conquerors", making historical metaphors thus doubly useful, as a heuristic tool and an argument.

11. If one adds occurrences in the context of colonisation in prehistoric, Ancient and Medieval times (24 matches) and lesser known internal colonisation in Europe (13 matches), historical uses of the term are in the majority ( $49 \%$, as opposed to $35 \%$ that relate to biology, medicine, and ecology).

12. Of the 339 matches of "cleansing" in the BNC, most refer to personal hygiene, housekeeping, street cleaning, and medicine (disinfection of wounds), i.e. the removal of dirt or bacteria.

13. "Other towns and cities with exceptionally high rates of births by non-UK-born mothers include Slough (58.9 percent), Luton (50 percent), Oxford (47.4 percent), Cambridge (45.4 percent), Leicester (44.8 percent), Watford, (44.8 percent), Reading (42.8 percent), Manchester (41.8 percent), Birmingham (38 percent), Peterborough (37.1 percent), Woking (36.9 percent) and Coventry ( 34.7 percent). Of course, none of the above figures takes into consideration the huge number of births to UK-born, non-indigenous, immigrants, making the true scale of the ethnic 
cleansing of the real British people much faster than disclosed" ["One-third of births in Britain are to foreign parents", www.bnp.org.uk, 30 November 2011].

14. "Butcher ran out of town by racist Muslim community", www.bnp.org.uk, 29 September 2012. 15. Such as the 2012-13 "Broken Britain" leaflet: "The BNP will freeze foreign aid until ALL British children are lifted out of poverty and British pensioners can afford to keep warm every winter".

16. "Northern Ireland - shocking sectarian killing by Republican movement exposes failure of Westminster and Stormont politicians", www.bnp.org.uk, 3 November 2012.

17. Although, paradoxically, far-right authors may on occasion also defend the record of European colonisation.

18. The disaster theme is sometimes directly mentioned, as for example in the expression "colonisation catastrophe" ["One Born Every Minute - Hiding the Third World Colonisation Catastrophe Through MSM Propaganda”, www.bnp.org.uk, 27 January 2012].

\section{ABSTRACTS}

Based on conceptual and discourse-oriented metaphor theory, the article argues that British farright discourse increasingly conceptualizes immigration with the help of martial rather than "fluid" or "container" metaphors. Metaphors such as "conquest", "colonization", and "ethnic cleansing" operate a semantic slide which transforms foreigners into "enemies" and seemingly justifies radical "emergency" measures against immigration. These implicit references to historical events convey specific notions of time and visions of the future.

\section{INDEX}

Keywords: historical metaphors, far-right discourse, immigration

\section{AUTHOR}

\section{ANNE FRIEDERIKE DELOUIS}

Université d'Orléans, France

anne.delouis@univ-orleans.fr 